IRSH 54 (2009), Supplement, pp. I67-I 88 doi:Io.I0I7/So020859009990289 (C) 2009 Internationaal Instituut voor Sociale Geschiedenis

\title{
The Dynamics of Working-Class Politics in Early Republican Turkey: Language, Identity, and Experience*
}

\author{
Y İĞİT A K IN \\ Department of History, Obio State University \\ E-mail: akin.ı6@osu.edu
}

Summary: The years between the late I940s and late I950s constituted a critical period in the historical formation of the working class in Turkey. During that period, Turkey experienced a number of structural transformations. It also saw the elaboration of a new discourse on the working class by labor representatives, organizations, and by workers themselves. That discourse provided the workers and their organizations with the channels necessary to articulate their demands when other forms of expression were considered ineffective and dangerous. Using the language of equality, justice, and human rights, workers appealed for improvement in their status both at the workplace and within society at large. This new political culture and language was built on the critical assessment of the corporatist construction of labor relations and the rejection of the idea that employers and workers were members of the same (national) family. Based on worker and union newspapers, the primary objective of this essay is to discuss the basic components and characteristic features of this new discourse and its place in working-class politics in early republican Turkey.

Apart from a few studies, Ottoman and early Republican Turkish labor history has been dominated by an essentialist, utterly materialist, teleological understanding of class. Based on a deterministic conception of class formation, this reductionist perspective presupposes that social classes would automatically emerge from the economic conditions and structures surrounding them. Under the weight of materialist analytical frameworks, the rank-and-file politics of workers, their mentalities, identities, and everyday experiences have virtually escaped scholarly attention. How did workers interpret their workplace experiences at

\footnotetext{
* I am grateful to Kyle Heatherly, Can Nacar, and Emre Sencer for their thoughtful comments and suggestions on earlier drafts of this article.
} 
various stages of industrialization? How did they construct their identity in reference to privileged classes and various other social strata? What cultural and ideological dynamics were critical in forging a distinct, collective identity? Historians of the Ottoman Empire and republican Turkey have recently started to wrestle with these key questions central to the history of class and class formation. In what follows, I seek to contribute to the ongoing discussion on the identities and experiences of workers in Ottoman/republican Turkish labor historiography.

My theoretical perspective is largely informed by the argument that, rather than reflecting a pre-existing reality, discursive systems and practices play an active role in constituting social reality. ${ }^{\mathrm{I}}$ This is not meant to reverse the deterministic relationship between the material and the cultural, by arguing that historical subjects and social processes are constructed merely through language and discourses. ${ }^{2}$ The relationship between discursive constructions and social and economic structures has a dynamic and complex nature. Discourses contribute to the formation of social relations, but they, in Laura L. Frader's words, "themselves exist in, and in relation with, the social world and are produced by conscious, acting subjects". ${ }^{3}$

My aim in this article is to highlight the importance of the culturally and discursively constructed dimensions of social relations between historical actors. In this sense, language, symbols, and cultural conventions have provided the context within which the material and non-material circumstances of workers' lives have been rendered meaningful. Based on this perspective, I maintain that in order to unravel the dynamics that governed working-class formation in the Ottoman Empire and republican Turkey, historians should not limit their analyses to the confines of socio-structural conditions. We need to go beyond purely materialist explanations of class

I. Neville Kirk, "History, Language, Ideas and Post-Modernism: A Materialist View", Social History, I9 (1994), pp. 22 I-240, 233; Joan Scott, "On Language, Gender, and Working-Class History", in Joan Scott, Gender and the Politics of History (New York, 1988), pp. 53-67; William H. Sewell, Jr, "Towards a Post-Materialist Rhetoric for Labor History", in Lenard R. Berlanstein (ed.), Rethinking Labor History: Essays on Discourse and Class Analysis (Urbana, IL, I993), pp. I 5-38. For the pitfalls and promises of this approach, see also Geoff Eley and Keith Nield, The Future of Class in History: What's Left of the Social? (Ann Arbor, MI, 2007); Kathleen Canning, "Feminist History after the Linguistic Turn: Historicizing Discourse and Experience", Signs, I9 (1994), pp. 368-404.

2. Marc W. Steinberg, "Culturally Speaking: Finding A Commons between Post-Structuralism and the Thompsonian Perspective", Social History, 2 I (1996), pp. I93-2 I4, I95. See also Donald Reid, "Reflections on Labor History and Language", in Berlanstein, Rethinking Labor History, pp. 39-54.

3. Laura L. Frader, "Dissent over Discourse: Labor History, Gender, and the Linguistic Turn", History and Theory, 34 (1995), pp. 21 3-230, 230. See also Geoff Eley, "Is All the World a Text? From Social History to the History of Society Two Decades Later", in Terrence J. McDonald (ed.), The Historic Turn in the Human Sciences (Ann Arbor, MI, 1996), pp. 193-243, 2 I 8. 
formation and examine the influence workers' self-perceptions and representations had on their class identities and consciousness. Such a perspective can help us to navigate issues that have been historically relegated to the margins of mainstream political and economic history. In this article, I employ this approach to rethink the development of Turkish workingclass identity and politics in the late r940s and r950s.

Turkish society underwent profound social, economic, and political transformations from the mid-I940s until the 1960s. ${ }^{4}$ With the end of World War II, governments launched a more liberal, market-oriented development strategy. ${ }^{5}$ Along with the mechanization and consequent increase in agricultural production, Turkey's industrial sector expanded and increased its contribution to national income. This period, in fact, corresponds to a remarkable growth of the working class. As the number and size of state and private enterprises increased, rural-to-urban migration accelerated its pace from the early i950s onward, and the industrial workforce population expanded significantly and huddled around large urban centers. During this period, Turkey also witnessed major changes in the regime's approach towards the labor question. Through a number of newly established institutions, laws, regulations, and, finally, a new hegemonic discourse, the state attempted to regulate the domain of labor relations with more and more rigor. To that end, the Ministry of Labor was founded in 1946, followed by the establishment of the Labor Placement Bureau [İş ve İşçi Bulma Kurumu], with the aim of coordinating the movement of labor. ${ }^{6}$

4. For a general overview, see Kemal H. Karpat, Turkey's Politics: The Transition to a MultiParty System (Princeton, NJ, 1959); Cem Eroğul, “The Establishment of Multiparty Rule: 1945-7I", in Irvin C. Schick and Ertuğrul Ahmet Tonak (eds), Turkey in Transition: New Perspectives (New York, 1987), pp. I0I-1 18; Feroz Ahmad, The Turkish Experiment in Democracy, I950-1975 (London, I977); M. Asım Karaömerlioğlu, “Turkey’s 'Return' to MultiParty Politics: A Social Interpretation”, East European Quarterly, 40 (2006), pp. 89-107.

5. Zvi Yehuda Hershlag, Turkey: An Economy in Transition (The Hague, 1958), pp. 177-277; William Hale, The Political and Economic Development of Modern Turkey (London, 198 I), pp. 86-I I 3; Çağlar Keyder, State and Class in Turkey: A Study in Capitalist Development (London, 1987), pp. I I7-I 40; Tolga Tören, Yeniden Yapılanan Dünya Ekonomisinde Marshall Plan ve Türkiye Uygulaması (Istanbul, 2007); Șevket Pamuk, "Economic Change in Twentieth Century Turkey: Is the Glass More Than Half Full?”, in Reşat Kasaba (ed.), The Cambridge History of Turkey IV: Turkey in the Modern World (Cambridge, 2008), pp. 266-300, 28 I-282.

6. For more on the policies toward labor in this period, see Yıldırım Koç, "Demokrat Parti, İşçiler ve Sendikalar", in Türkiye'de Issçiler ve Sendikalar (Taribten Sayfalar) (Ankara, 2000), pp. 35-85. See also Fatih Güngör, "I946-I960 Döneminde Türkiye'de Sendikac1lı Hareketi ve Demokrasi”, in Alpaslan Ișıklı (ed.), Türkiye'de Sendikacllık Hareketleri İçinde Demokrasi Kavramınm Gelişimi (Ankara, I994), pp. I3 I-I90; M. Görkem Doğan, "Governmental Involvement in the Establishment and Performance of the Trade Unions during the Transition to Multi Party Politics: The Case of the Worker's Bureau of the Republican People’s Party" (M.A. thesis, Boğaziçi University, Istanbul, 2003); Ahmet Makal, "Türkiye'nin Çok Partili Yaşama Geçiş Sürecinde Cumhuriyet Halk Partisi ve Sendikalar: 1946-1950", in Ahmet Makal, Ameleden İşciye: Erken Cumburiyet Dönemi Emek Taribi Çalıșmalarn (Istanbul, 2007), pp. $213-265$. 
The years between the late i940s and late i950s also constituted a critical period in the historical formation of the Turkish working class. ${ }^{7}$ After the Trade Union Act of 1947 legalized workers' organizations, they proliferated in number and became actively involved in working-class politics, a process which had repercussions for the political and intellectual temperament of the country. ${ }^{8}$ Between 1948 and 1963, trade-union membership rose almost six-fold, though this number still corresponded to a minor fraction of the working population. ${ }^{9}$ Despite some serious difficulties in attracting agricultural workers and construction workers to unionization, trade unions managed to reach higher levels of unionization in the railroading, coalmining, local transportation, textile, public utility, and tobacco manufacturing industries.

Along with these structural transformations, one cannot fail to notice the elaboration of a new discourse on the working class by labor representatives, organizations, and by workers themselves. This discourse provided the workers and their organizations with the channels necessary to articulate their demands when other forms of expression were considered ineffective and dangerous. Using the language of equality, justice, and human rights, workers appealed for improvement in their status both at the workplace and within society at large. The primary objective of this essay is to discuss the basic components and characteristic features of this new discourse and its place in working-class politics in early republican Turkey.

Worker newspapers published in the period under consideration constitute the major source of this study. The flourishing of labor and union newspapers can be understood only in the light of the significant growth of the Turkish press following World War II. From the mid-I940s on, the volume and circulation of newspapers throughout the country increased drastically. ${ }^{\mathrm{IO}}$ This proliferation of print media was paralleled by the mounting influence of the press on current political and social developments.

7. For a similar interpretation, see Hakan Koçak, "50'leri İşçi Sınıfı Oluşumunun Kritik Bir Uğrağ Olarak Yeniden Okumak”, Çalıșma ve Toplum, I 8 (2008), pp. 69-85; Sinan Yıldırmaz, “Demokrat Parti ve Dönemi: Sol Tarihyazımında 'Kayıp' Zamanın İzinde”, Praksis, i 8 (2008), pp. $23-42$.

8. Cahit Talas, Türkiye Cumburiyeti'nde Sosyal Politika Meseleleri (I920-1960) (Ankara, 1960), p. 23; Yıldırım Koç, “I947 Sendikalar Yasası”, Mülkiyeliler Birliği Dergisi, I2 I (1990), pp. I0-I4; Kemal Sülker, Türkiye Sendikacılık Taribi (Istanbul, 1987), pp. 54-94 and passim. 9. Ahmet Makal, Türkiye'de Çok Partili Dönemde Çalışma İlişkileri, I946-1963 (Ankara, 2002), p. 276.

ı. For a detailed analysis of this phenomenon, see Gavin D. Brockett, "Betwixt and Between: Turkish Print Culture and the Emergence of a National Identity, 1945-1954" (unpublished Ph.D. dissertation, University of Chicago, 2003); Kemal Karpat, "The Mass Media: Turkey”, in Robert E. Ward and Dankwart A. Rustow (eds), Political Modernization in Japan and Turkey (Princeton, NJ, 1964), pp. 255-282, 277-282. 
Various social groups came to realize how newspapers and journals could be used to express and disseminate their views with the aim of affecting policy-making.

Aside from sporadic and short-lived attempts in preceding periods, for the first time in modern Turkish history newspapers placing a special emphasis on the issues that directly bore on the working class began to emerge in this period. ${ }^{\text {I }}$ These newspapers and journals were published by private publishers and regional union organizations on weekly, fortnightly, or monthly bases. Some of them disappeared after publishing only one or two issues, but some survived the financial and managerial difficulties that typified print media in this period. These successful newspapers and journals attempted to find an audience by covering the recent news regarding the labor movement and governmental policies on labor and trade unions, including educational columns on labor laws and legislation as well as health, hygiene, and the family, and by publishing essays, poems, and letters written by workers. All of these newspapers aimed at intervening in the "labor question" (işşi davası) on the workers' side, some explicitly, some in more subtle ways. They intended to reflect workers' opinions and provide information on their problems, which many felt were disregarded by the mainstream media. The inaugural issue of Sendika Yolu [Union Way], for example, proclaimed:

[...] the Turkish press has not so far paid the attention to the laboring masses that they deserve and has not defended them against social inequalities. [...] Realizing that nobody but ourselves would be willing to give the heart and soul necessary to defend us [bizi bizden gayri kimsenin canı gönülden müdafaa etmeyecegini idrak ederek] [...]. We publish this newspaper in order to bequeath the historical records of our struggle against your [employers' and supervisors'] arbitrary orders. ${ }^{\mathrm{I}}$

These mostly untapped sources provide remarkable insights into the politics of working-class identity at this critical juncture of Turkey's history. These sources, however, are not without their problems. The writers of these newspapers did not always come from the ranks of ordinary workers. Although some writers were workers or former workers, others might have been local union leaders or local intellectuals involved in working-class politics. Nonetheless, the publishers and writers of these newspapers and ordinary workers were not living in two different, isolated worlds. As their writings demonstrate, they had an intimate knowledge of workers' everyday

II. For more information on the emergence and development of the worker/union press, see "Sendika Basını", in Türkiye Sendikacalık Ansiklopedisi, 3 vols (Istanbul, I996), III, pp. I 2-I6. I 2. Celal Ülkü, “Gazetemizi Niçin Çıkarıyoruz?”, Sendika Yolu, I (I 8 August 1948), pp. I, 4. The Sendika Yolu was published between August 1948 and November 1949 in Nazilli. It was the official newsletter of the Nazilli Textile Industry Workers' Union (Nazilli Mensucat Sanayii İşçileri Sendikası). On Sendika Yolu, see Türkiye Sendikacılık Ansiklopedisi, III, p. 35. 
lives, their troubles, and their mental worlds. They tried hard to reflect upon workers' real concerns and to mitigate their problems. ${ }^{{ }^{3}}$ Material in these newspapers, therefore, cover an impressive range of subjects from vivid firsthand descriptions of working and living conditions to vehement complaints about wages, working hours, and employers.

It would also be misleading to assume that the workers' understanding of their place in the social order was shaped solely by discourses developed by the working-class movement. Workers' identities were influenced by a number of factors such as gender, skill, age, experience, sector, ethnicity, religious devotion, and ties to the countryside, to name but a few. Furthermore, the degree to which workers subscribed to these discourses and identified themselves with the representations in labor newspapers is hard to gauge. They may indeed have adopted certain aspects of various discourses and rejected others. Nevertheless, until we discover more authentic sources, this unexploited material might offer labor historians invaluable information and a rare glimpse into the formation and representation of working-class identity.

The political, ideological, and cultural developments in post-World-War-II Turkey created an environment conducive to the emergence of a new discourse on workers and their identity. It is therefore not surprising to note that labor newspapers' emphasis on rights and justice bore striking parallels to the pervasive populist rhetoric of the period. As is well known, the transition from single-party rule to a multi-party regime in Turkey spawned a new vocabulary of political discourse. ${ }^{14}$ Even though they did not always agree on the meanings and practical implications of "new" notions such as freedom and democracy, various political actors felt increasingly obliged to draw on them. Especially during the election campaigns of I 946 and I950 (as well as the years in between), workers and their representatives became increasingly acquainted with the concepts of citizenship rights, equality, freedom, justice, oppression, despotism, and tyranny which the Democrat Party deployed to attract both urban and rural voters to its side. Workers, as discussed below, consciously played on this rhetoric in order to achieve their goals. ${ }^{\mathrm{IS}}$

In line with this new vocabulary, a striking feature of worker newspapers was their staunch anti-communism and hatred of communists.

I3. Occasionally, competition between rival unions also played an important role in this aspect. In order to attract more workers to their side, union newspapers tried hard to give the impression that they were highly sensitive to workers and their demands.

I4. İlkay Sunar, "Populism and Patronage: Democrat Party and its Legacy in Turkey", in State, Society and Democracy in Turkey (Istanbul, 2004), pp. I 2 I-I34; Reşat Kasaba, "Populism and Democracy in Turkey, 1946-196r”, in Ellis Goldberg, Reşat Kasaba, and Joel Migdal (eds), Rules and Rights in the Middle East (Seattle, WA, 1993), pp. 43-68.

I 5 . See, for example, the rhetoric of some trade unions on the right to strike and collective bargaining; Kemal Sülker, Türkiye'de Grev Hakkı ve Grevler (Istanbul, I976), pp. 8 I-90. 
In I940s and I950s Turkey, the political and cultural atmosphere was extremely unfavorable towards any socialist or communist activity. ${ }^{16}$ During the Cold War, Turkey became one of the strongholds of the liberal/capitalist world against the ideological and cultural expansion of communism. A newly joined member of NATO, Turkey was actively involved in the Korean War, an incident which dramatically strengthened anti-communist sentiment throughout the country. ${ }^{17}$ At the hands of the consecutive CHP (Cumhuriyet Halk Partisi - Republican People's Party) and DP (Demokrat Parti - Democrat Party) governments, anticommunism served as a powerful tool to suppress left-wing political parties and trade unions and persecute their members. In line with this staunch anti-communist mood, worker newspapers were filled with news about the suffering of laborers under communism and the brutality of communist regimes. The newspapers may have subscribed to this extreme rhetoric for the sake of avoiding any legal sanctions. Out of fear of being associated with communism, they put a great effort into displaying their anti-communist fervor. It would be misleading, however, to assume that they adopted an anti-communist stance simply to hoodwink the government. Workers, at least a certain number of them, and their representatives heartily shared an aversion to communism and communists.

The new discourse elaborated in worker newspapers and other similar venues was primarily based on a heightened sense of worker identity. In this period, workers' organizations consciously and vigorously propagated the idea that being a worker was not something of which to feel ashamed. ${ }^{18}$ They encouraged laborers to identify themselves positively as workers belonging to the broader laboring community. ${ }^{19}$ As the material

I6. For the Cold War and anti-communism in Turkey, see Derya Çağlar, Hayali Komünizm: Soğnk Savaş’nn Türkiye Söylemleri (Istanbul, 2008); Yüksel Taşkın, “Anti-Komünizm ve Türk Milliyetçiliği: Endişe ve Pragmatizm”, in Tanıl Bora (ed.), Modern Türkiye’de Siyasi Düşünce IV: Milliyetçilik (Istanbul, 2002), pp. 61 8-635.

17. Gavin D. Brockett, “The Legend of 'The Turk' in Korea: Popular Perceptions of the Korean War and Their Importance to a Turkish National Identity", War E Society, 22 (2004), pp. I09-142. I8. For instance, one of the first working-class organizations founded in the aftermath of the war, Türkiye İşçiler Derneği [Turkey Workers' Society], announced its projected goals as to endeavor "to maintain the material and spiritual comfort of workers and to give them the honor they deserve" (işçilerin maddi, manevi rahatlarını temine hizmet etmek ve işçilerin layık olduğu şerefi canlandırmak) (my emphasis); see Sülker, Türkiye Sendikacılık Tarihi, p. 40.

19. This new direction in working-class discourse was not limited to the content of the material published in these newspapers. It can also be observed in writers' careful use of language. In place of the more disparaging amele or irgat, for example, labor newspapers always preferred the term işçi, with its connotation of “skilled laborer". Indeed, the Workers' Group at the Izmir Economic Congress of 1923 proposed to designate male and female workers as işçi instead of the commonly used amele; Ahmet Gündüz Ökçün, Türkiye İktisat Kongresi I923 - Izmir: Haberler, Belgeler, Yorumlar (Ankara, 197I), p. 430. By and large, however, this proposal remained on paper. 
in these newspapers testified, workers simultaneously became aware of their position in society, their role in the production process, and their rights as citizens. ${ }^{20}$ In an increasingly vocal way, they raised their requests for higher wages, supplemental benefits, and better working and living conditions. Furthermore, they also demanded justice, equality, and humane and dignified treatment from their supervisors, employers, and from other privileged classes in society. In this respect, workers' concerns were not limited to economic issues; they also included social and moral dimensions.

Despite their strong emphasis on workers' identity and their specific problems, the writers of the newspapers did not employ the terms "worker" or "working class" in a way that excluded other segments of society. They had a strong sense of fellowship with the poor and underprivileged (balk tabakast), who were suffering from the same kind of injustice, impoverishment, and maltreatment. For example, acclaiming the government's attempt to launch a new regulation imposing a minimum wage, a union journal wrote that without a fair minimum wage the working-class mass, which constituted 85 per cent of the population, would either fall into destitution, resulting in a horrible series of deaths, or they would be forced to migrate. ${ }^{21}$ Given this inclusive attitude, Isş̧i Dünyası [Worker's World] adopted a critical stance against the official definition of "worker" in the Labor Law of 1936. The definition in accordance with the Law, the newspaper argued, was quite narrow and should be expanded: "All of us, except the children and the elderly, are workers." ${ }^{22}$ Expressing the identity of "the worker" in a way that cut across the differences between the lower classes and embraced all of them was a common feature of worker newspapers. Accordingly, a union member could bring the problems of agricultural laborers and industrial workers together in the same article without noting any tension between them.

If association with other lower classes was one dimension of workers' sense of themselves, enmity towards privileged social groups was another.

20. A columnist in Sendika Yolu, for instance, wrote that society owed every single achievement in the world to the "creative power of the worker". In the remainder of this interesting article, the writer gave the example of Sinan the Architect, who was nothing but "a simple but dignified Turkish worker"; Baha Macit Karabağlı, "Medeniyeti Kuran ve Hayatımızı Koruyan Adam", Sendika Yolu, 2 (25 August 1948), p. 3.

2 I. "[...] nüfusumuzun yüzde seksen beșini teşkil eden işçi kütlesi ya sefalete sürüklenecek ve dolayısiyle korkunç bir şekilde vefiyat başlayacaktı, veyahut hicret etmek mecburiyetinde kalacaktı"; G.İ.P, "İşçi ve Asgari Ücret”, Güney İşçi Postası, 22 (10 March 1952), p. I (my emphasis). Güney Isş̧i Postası was published in Adana between I95 I and March I952 on a weekly basis, and ran to twenty-two issues. Yüksel Akkaya, "Çukurova'da Sendikacıllk ve İşçi Eylemleri, I923-1960”, Kebikeç, 5 (1997), pp. I83-200, 192.

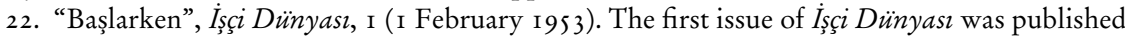
in Ankara in February 1953. The newspaper adopted a policy of publication in line with the newly founded Türk-İș; Türkiye Sendikacılık Ansiklopedisi, II, pp. I02-103. 
Workers' anger was generally directed against the figure who personified all the acts they complained about, the employer. ${ }^{23}$ Seen as constantly ignoring workers' demands, forcing them to work tirelessly, and sidestepping official rules and regulations, the employers were routinely denounced as selfish, cruel, heartless, devilish, remorseless, barbarous, and much else besides. Workers frequently thought of their factory bosses as the embodiment of callousness, greed, and unlawfulness.

It was also a commonplace to use the metaphor of slavery to describe relations between workers and their employers. In many respects, workers and labor unions maintained, the current status of labor relations replicated owner-slave relations. Reporting on the harsh working conditions during the construction of Zonguldak harbor, Ișçi Dünyası critically asked: “Aren't there legal sanctions to show these men that the workers they employed are not slaves? We are apt to think that slavery has vanished from the world." ${ }^{24}$ In a similar vein, "some employers keep considering relations between worker and employer in terms of the relationship between SLAVE and OWNER", wrote a columnist resentfully. "As if the workers' labor makes no contribution to their affluent lives, [employers] resort to all kinds of devilish tactic in order to seize the last bit of these modest and self-sacrificing people." ${ }^{25}$ In its inaugural issue, Sendika Yolu declared that by publishing the newspaper, they wanted to struggle against the mentality which regarded the worker as "his father's slave" (babasinin kölesi). ${ }^{26}$ Workers strongly impugned the integrity of their employers by pointing out the apparent contradiction between the employers' desire for a more liberal and market-oriented economy and their wanton disrespect for basic human rights. "It is a shame that a number of people who decry the lack of private enterprise still do not recognize human rights, and thus adhere to an exploitative mentality." ${ }^{27}$

23. This is, indeed, reminiscent of E.P. Thompson's oft-quoted dictum that "class is a social and cultural formation (often finding institutional expression) which cannot be defined abstractly, or in isolation, but only in terms of relationship with other classes; and, ultimately, the definition can only be made in the medium of time - that is, action and reaction, change and conflict"; E.P. Thompson, "The Peculiarities of the English", in Ralph Miliband and John Saville (eds), Socialist Register 1965 (London, 1965), p. 357 (original emphasis).

24. "Hollanda Şirketi Esir mi Çalışstırıyor? Zonguldak Liman İnşaatı Hazin Bir Durumda", İşçi Dünyası, I (I February 1953), p. I. Labor disputes with foreign firms became heavily charged with emotion as the acts of these firms were also perceived as offensive to national pride.

25. "Sürdükleri müreffeh hayatı yaşamalarında işçilerinin payı yokmuş gibi bu feragatkâr ve fedakâr insanların ellerinden son lokmalarını da almak için her türlü șeytaniyete başvuruyorlar"; Yenihamle, "Ne İstiyorlar?”, Güney Isşçi Postası, I9 (I I February 1952), p. 2. 26. Ülkü, "Gazetemizi Niçin Çıkarıyoruz?”, p. 4.

27. "Hususi teșebbüse yer verilmiyor diye bağıran bir sürü insanın, daha hala insan haklarını tanımamak suretile istismarcı bir zihniyet içinde yüzüp durmaları, bu memleketin iktisadiyatı ve kendileri için çok hazindir." "Mensucat Sanayii İşçileri Sendikasında Yapılan Mühüm Toplantı”, Isşci Sesi (Bursa), 9 (23 October 195 I), p. I. İşçi Sesi was published in Bursa initially by 
Labor newspapers deliberately presented the employer's greed and the worker's modesty and generosity in stark contrast to one another. While the worker was described as someone who could barely eke out a living, the most salient characteristic of the employer became his avarice and selfishness. Isş̧inin Sesi [The Worker's Voice], for instance, mentioned well-to-do people "who would not be satisfied even if they were given Eskişehir; they would still strive to acquire the Konya Plain". ${ }^{28}$ Perhaps no writing captured workers' antagonism towards their employers better than the cartoons published in worker newspapers (see Figures I and 2). These cartoons seem to be the visualization of what they wrote about the employers.

Despite the existence of certain protective laws and regulations on labor, workers and unions thought that these simply existed on paper as their implementation was subject to the employer's will. Workers firmly believed that employers had the power to avoid laws and regulations pertaining to labor issues. ${ }^{29}$ In November 195 I, for instance, $\dot{I}_{\text {şçi Sesi listed eight factories }}$ in Bursa that violated the Labor Law. These factories did not keep official records of workers in order to evade official obligations, did not let them elect factory representatives, and forced them to work eleven hours without overtime pay. The newspaper asked "Is it the law or arbitrary treatment that governs these factories?". ${ }^{\circ}$ This was one of the burning issues which labor leaders underscored consistently throughout the period under consideration. At the Saraçhane Meeting of I96I, Kemal Türkler, President of the Türkiye Maden-İş Union, asserted that some employers scorned workers' demands, quoting one employer as saying, "I constructed the walls of this factory high. The law cannot get in here. My law is money." ${ }^{11}$ (A cartoon (Figure 3, p. I79)

a private publisher, then by the Bursa Textile Industry Workers' Union [Bursa Mensucat Sanayii İşçileri Sendikas1]. A total of thirty-four issues of the newspaper were published between I95 I and 1952.

28. "Ancak bunların içerisinde o kadar muhteris ruhlu olanları var ki, Eskișehir senin desen yine doymaz. Konya Ovası'nı da kendine mülk etmeye çalışır”; Isş̧̧inin Sesi, 4 (29 October I95 I), p. I. İşcinin Sesi was published in Eskișehir between September I95 I and December 1954 on a fortnightly basis. Its owner and editor-in-chief was Riza Tetik, who was one of the leaders of Eskișehir Railway Workers' Union; Türkiye Sendikacıllk Ansiklopedisi, III, p. 2 I4.

29. In December 1947, a commission formed by MPs recorded the "innovative" methods used by employers to circumvent labor laws and regulations; Bazı Bölgelerdeki Fabrika, Isyerleri ve Isş̧ilerin Genel Durumu Hakkında BMM Çalışma Komisyonu'ndan Bir Grubun Hazırladrğ Rapor (30 December 1947), Prime Ministry Republican Archive CHP Catalog 490.0I/ 728.495.5. For similar observations, see Orhan Tuna, Grev Hakkı: Ișs Mücadelelerinde Yeri ve Ehemmiyeti (Istanbul, I951), p. 55.

30. "Kanun mu Yoksa Keyfi Muamele mi Hakim? İşyerinde İşverenlerin İşçiyi Hangi Şartlarla Çalıştırdıkları Meydana Çıkıyor?”, İşçi Sesi (Bursa), I I (6 November 195 I), pp. I, 3.

3 I. Türkiye Sendikacillk Ansiklopedisi, II, p. 567. The Saraçhane Meeting of 1961, which more than one hundred thousand workers attended, was arguably the greatest mass demonstration in Turkish working-class history until that time. 


\section{Patronun çkart}

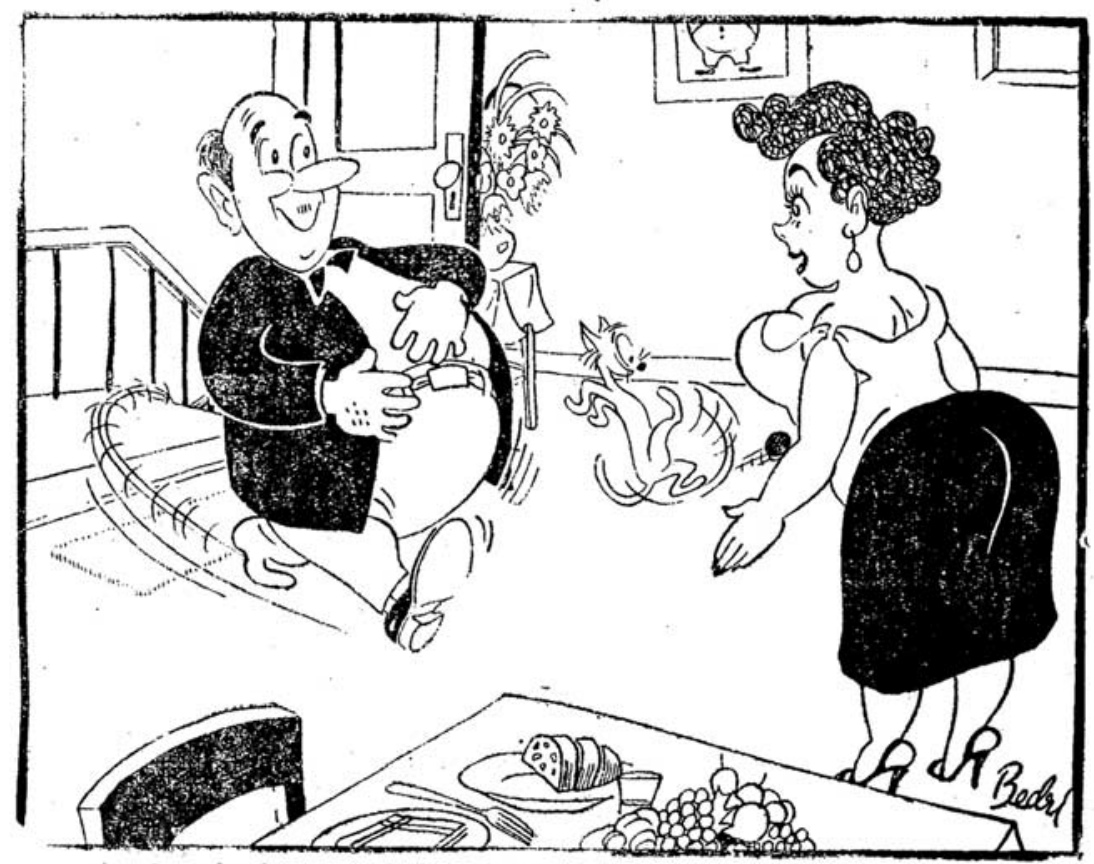

- Ayol nedir karnının hali öyle ?

- Iş̧̧ler ziyafet vermişlerdi, bir haftalık yevmiyelerin acısııı çıardım|

Figure I. İ̧̧̧̧i Sesi (Bursa), no. 9, "Employer’s interest".

"Wow! What happened to your belly?"

"Workers gave a feast. I’ve made up for their weekly wages."

published in Iş̧i Sesi (Bursa), for instance, powerfully described the attitude of employers towards labor regulations.)

The state's place in this dichotomous relationship was rather ambivalent. On the one hand, especially in the early 1950s, workers and their organizations appreciated the Democrat Party's attempts to prepare new regulations to implement a minimum wage, adopt new measures to ameliorate working conditions, and expand the official scope and coverage of the Labor Law. ${ }^{32}$ On the other hand, they continuously pointed to serious problems in the world of labor and complained about the lack of any discernible improvement in their standard of living. In the discourse of workers, the state and its institutions, which were charged with the enforcement of the labor laws, frequently appeared as slow, ineffective, and mostly indifferent to government's draft bill on "the right to strike”, see Sülker, Türkiye'de Grev Hakkı, pp. I79-i 86. 


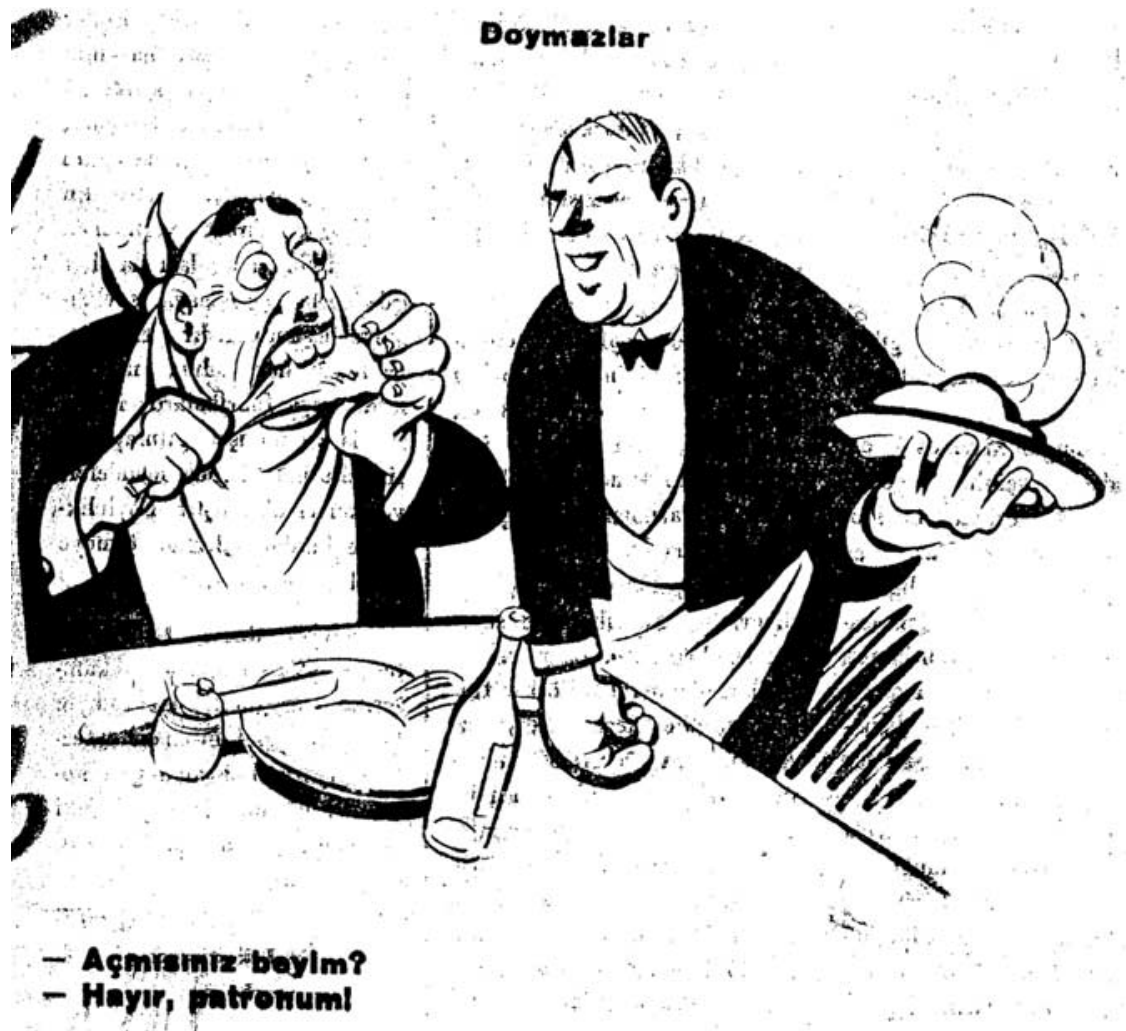

Figure 2. İş̧i Sesi (Bursa), no. I4, "They don't get full”.

"Are you hungry, Sir?"

"No, I am an employer."

workers' problems (Figure 4, for example, ridicules the indolence of local labor agencies). In August I95 I, a worker newspaper wrote furiously that the Ministry of Labor and local labor agencies had lost the promptness and interest they once had at the beginning of the period. ${ }^{33}$

Workers were also aware of the widespread collaboration between local state officials responsible for labor issues and employers and managerial employees. One worker newspaper claimed that labor inspectors informed employers in advance of their inspection visits. The director of the local labor bureau and his labor inspectors were also seen strolling arm-in-arm with employers. ${ }^{34}$ Under these circumstances, the newspapers

33. Sabri Türkozan, "Sendikalar Kırtasiyecilikten Şikayetçidir”, İş̧i Sesi (Bursa), 8 ( I s October I95I), p. 2.

34. "Mensucat Sanayii İşçileri Sendikasında Yapılan Mühüm Toplantı", İşçi Sesi (Bursa), 9 (23 October I95 I), p. 3. 


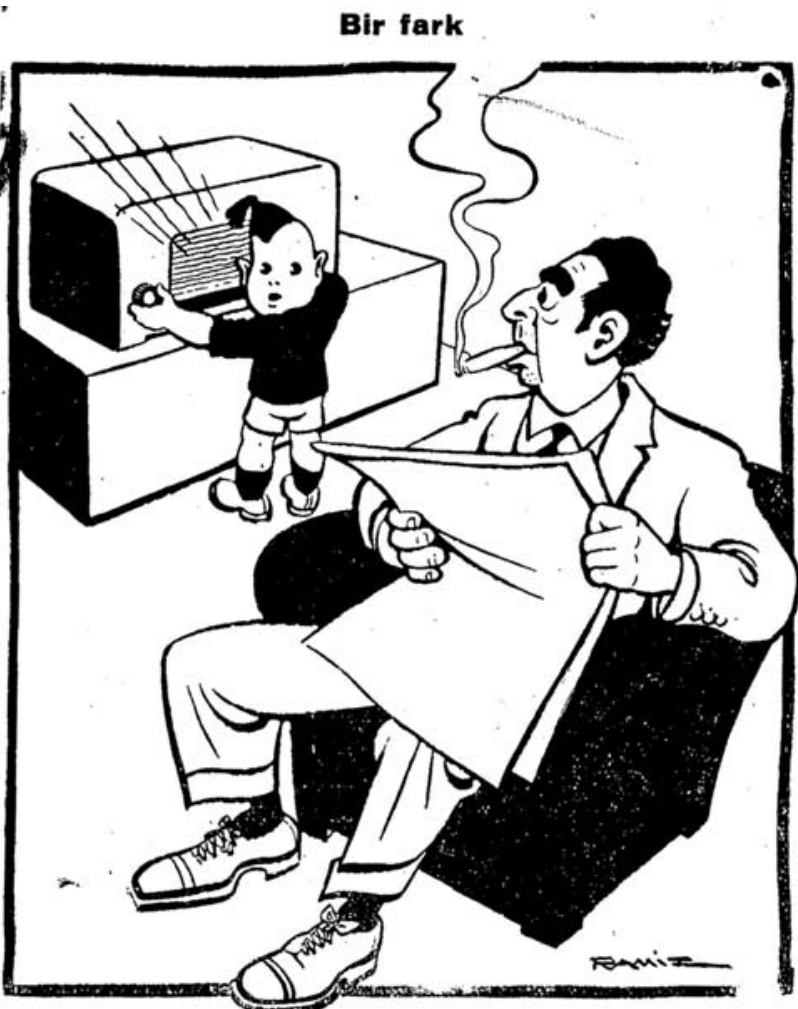

- Bak babal Iş̧̧̧i hakları diye bir şeyler söylüyorlar.

- Radyoda söylerler amma, fabrikada kimse ağzını açamazl

Figure 3. İş̧̧ Sesi (Bursa), no. I I, "A difference".

"Look, Dad, they talk about something called workers' rights."

"They talk on the radio, but nobody can open his mouth at the factory."

claimed, employers did not feel any official pressure to make more than perfunctory gestures towards compliance with the existing laws and regulations. Government agencies fell short in ensuring the adherence of employers to legal requirements. Disappointed by the new government's impotence in providing social justice, one worker sarcastically wrote, "How enchanting were you, oh social justice! We have become your slave of love, though we drowned in poverty." 35

35. "Ne efsunkâr imişsin ah hey içtimai adalet/Esir-i aşıkın olduk gerçi boğulduk sefaletten!"; Hasan Özgüneş, "Ne Efsunkâr Imişsin Ah Hey Içtimai Adalet", İşçi Sesi (Adana), 25 (I3 December 1950), p. 2. Actually, these verses carried a reference to Namik Kemal's 


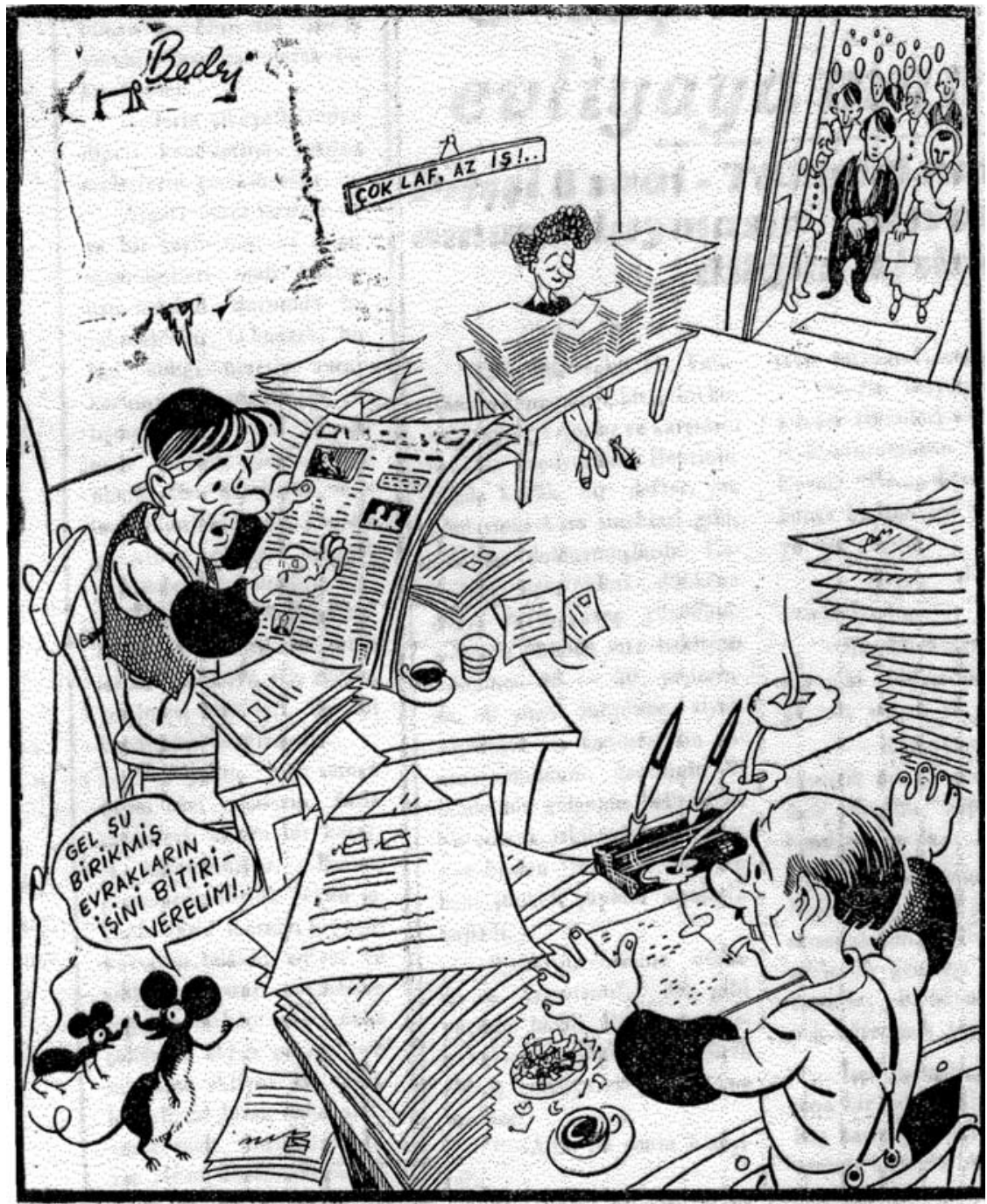

Çaıß̧ma toşkilâtının işini bitirmok Miki Maus arkadaşlara kalıyor!

Figure 4. Isş̧i Sesi (Bursa), no. I 2, "The duty of finishing the job of the Labor Agency falls to Mickey Mouse friends".

"Come, let's finish those accumulated documents."

well-known poem Hürriyet Kasidesi. Similarly, in a possibly fictitious interview, a female worker, Nefise, responded to a question by saying she would light a candle for the saints if she came across the Labor Agency [Çalıșma Teşkilatı]; "O Teşkilatı Bir Görsem Evliyaya Mum Adardım!”, Isşçi Sesi (Bursa), I 2 (I 3 November 195 I), pp. 2, 4. 
This critical language positioned the workers in conflict with their employers and was at complete odds with the dominant ideology on labor relations propagated by the Kemalist regime. Denying the existence of social classes in Turkish society, the early republican regime endeavored to define the relationship between employers and employees through familial metaphors. According to this perspective, a peaceful, harmonious relationship prevailed at the workplace because both employees and employers were perceived as agents of the nation's industrialization. ${ }^{36}$

Contrary to official rhetoric on labor relations, worker newspapers continuously implied that workers did not owe a debt of gratitude to employers simply because they provided them with employment. Even when they used a conciliatory tone in their appeals to the state and employers, workers rarely evoked the rhetoric of sympathy, submissiveness, or paternalism but preferred the language(s) of rights, human worth, and rationality. Whenever they asked for wage increases, an equitable distribution of benefits, or improvement in working and living conditions, they did not submit to employers' benevolence. On the contrary, they sought to formulize their demands either within the framework of basic citizenship rights, or entitlements based on service to the factory or as an indispensable precondition for high productivity. ${ }^{37}$ Thus it was not a coincidence that some of the banners carried by workers at the Saraçhane Meeting bore slogans such as "Lütuf degull, hak istiyoruz" [Not condescension, but rights], "Harpte en öndeyiz, hakta en arkadayzz" [Up front in war, way behind in rights], and " $B u$ vatanda nimet de külfet de müsterek" [In this land, blessings and burdens are shared]. ${ }^{38}$ As they saw themselves both as citizens and as important elements of industrial production, workers believed that they ought to be accorded a certain value materialized in humane treatment, higher wages, shorter working

36. For the corporatist orientations of the early Republican regime, see Ahmet Makal, "Türkiye'de Tek Parti Dönemi Korporatizm Tartıșmaları”, Toplum ve Bilim, 93 (2002), pp. 173-199; Aykut Kansu, "Türkiye'de Korporatist Düşünce ve Korporatizm Uygulamaları”, in Ahmet İnsel (ed.), Modern Türkiye'de Siyasi Düşünce II: Kemalizm (Istanbul, 2001), pp. 253-267; Hakkı Uyar, "Devletin İşçi Sınıfı ve Örgütlenme Girişimi: CHP İzmir İşçi ve Esnaf Cemiyetleri Birliği (1935)", Tarih ve Toplum, I60 (I997), pp. I4-20; Y1ldırım Koç, "I923-1950 Döneminde CHP’nin İşçi Sınıfı Korkusu”, Mülkiyeliler Birliği Dergisi, I70 (1994), pp. 43-44. See also Yüksel Akkaya and Fatih Güngör, "Düzen ve Kalkınma Arayışları İçinde Türkiye'de Sendikacılık ve Milliyetçilik", in Tarib ve Milliyetçilik: I. Ulusal Tarib Kongresi-Bildiriler (Mersin, 1997), pp. 400-419.

37. Isşiye Hizmet, published in Izmir, for example, criticized union representatives who used phrases like "lütfen" [please]," "merhameten" [compassionately], and "Allah rızası için" [for God's sake] when dealing with employers; B.A., "Sendika Basamak Değildir”, İşçiye Hizmet, 3 (2 I May 1953), p. I. The first issue of Issciye Hizmet [Service to the Worker] was published in May 1953 in Izmir. However, we have no information on how long the newspaper continued publication.

38. Türkiye Sendikaculık Ansiklopedisi, II, p. 567. 
hours, and better working conditions. They also maintained that if the workplace performance of some workers fell short of the desired standards, it was not their fault, but the fault of the employers who failed to fulfill workers' basic demands and the state agencies that failed to enforce prevailing laws and regulations in factories and workshops. ${ }^{39}$

In the language of the workers, the idea of economic justice was expressed in terms of human dignity and equal rights. Workers continuously articulated their grievances about wages, working hours, and working conditions within the framework of the right to live an honorable life. Extremely hard working conditions and low wages were understood by workers and their representatives as a critical issue that violated human dignity. In order to have a life worthy of a human being, they stressed that wages should be increased and working conditions improved. Kemal Üre, a car mechanic, described the situation of workers and their basic desires as such:

The Turkish worker has always been a toy in the hands of the employers. S/he has worked hard, but earned little; has become sick; has lived in misery; has died; s/he could not bequeath to his/her children anything but suffering. Today we don't want to work a little and earn a lot. What we wish is the recognition of our most basic right: the right to be a human being..$^{\circ}$

The language of workers and of their representatives became increasingly poignant when they described their miserable living and working conditions. Hundreds of dock workers in the Izmir harbor (who stopped loading and unloading operations to protest against the contractor) exclaimed to the governor, public prosecutor, and chief of the police department that they could not live on the 20-25 lira they earned weekly and that they and their wives had started sleeping in separate beds to avoid having a baby which they could not raise properly due to financial difficulties. ${ }^{4 \mathrm{I}}$ Using the columns in their newspapers, workers did not hesitate to react promptly to those who contravened their dignity and ignored their basic rights. Güney Isş̧i Postası [Southern Workers' Mail], for instance, criticized the director of the Labor Bureau in Adana who was commissioned to prepare a specific cost of living index for working-class families. The director, according to the newspaper's report, refused to apply a middle-class cost of living index to working-class families. "Aren't you aware of the fact that we are an unprivileged, classless society? Sure, you are! [...] A working-class family needs the same to cook a pot of food

39. See for example "İşçilerin Kalkınmasını İstiyorsak Bu Dava Ele Alınmalıdır", Sendika Yolu, 32 (I7 August 1949), p. 2; "Hastalık ve İstirahat Yevmiyeleri”, İs Yolu (Karabük), I 8 ( I October I952), p. I.

40. Kemal Üre, "Türk İşçisi”, Sendika Yolu, I (18 August I948), p. 3.

41. Sülker, Türkiye'de Grev Hakkı, p. I65. 
as others." ${ }^{22}$ Workers constantly expressed their concerns regarding the low level of wages, with an implied hope that, through wage increases, they might attain a tolerable life and cope with the high inflation which had plagued the country since the end of World War II.

The issue of long working hours was a constant source of strife between workers, employers, and state officials. Workers almost invariably listed the establishment of the eight-hour working day and overtime pay among their objectives and as two of the prerequisites for a humane life. They regularly attacked employers who infringed upon labor standards and regulations. A columnist in Iş̧̧i Gü̈ü [Workers' Power] bitterly asked: “How do we work? How [under what conditions] are we employed? Is this way of working humane? Does anyone care?" Then he went on to appeal sarcastically to the IETT (Istanbul Municipal Administration of Electricity, Tramway, and Tunnel) administration; he recommended they import a couple tons of newly invented energy pills to keep up the stamina of workers. ${ }^{43}$

Similarly, at the meeting of workers at the Bursa Textile Industry Workers' Union [Bursa Mensucat Sanayii İşçileri Sendikasi] labor representatives complained about inhumanely long shifts. As one representative maintained, "disregarding every rule and regulation, workers were forced to work seventeen to eighteen hours a day, seven days a week without a single day off. Those who asked for a day off were fired. Day and night workers have wasted their lives." ${ }^{44}$ Similarly, female workers at cocoon factories were obliged to work fifteen to seventeen hours even on summer days, when shifts were traditionally short due to warm weather. Employers also resorted to several tactics to get around the law regarding paid weekend rest. The owner of the Tokur Textile Factory in Bursa, for example, paid weekly wages on Sundays instead of Saturdays in order to bring workers into the factory on their day off. ${ }^{45}$ A worker newspaper, for

42. "[...] imtiyazsız sınıfsız bir millet olduğumuzdan haberleri yok mudur? Şüphesiz ki vardır. [...] Bir işçinin evinde bir tencere yemek kaynatabilmek için neye ihtiyacı varsa, diğerinin de aynıdır"; Muhittin Gediklioğlu, "Yazık Oldu Emeklere”, Güney İş̧i Postası, I9 (I I February 1952), p. I.

43. "Nasıl çalışıyoruz? Nasıl çalıştırılıyoruz? Bu çalıștırma insanca mı? Kimin umurunda?”; M. Hasip Gürak, "Enerji Hapları", Isşçi Gücü, 38 (I 8 June 1953), p. 3. A slightly earlier study had pointed to the poor living and working conditions among tramway workers employed at the IETT; Ziyaeddin Fahri Fındıkoğlu, İstanbul'da Şehir İçi İnsan Nakli Meselesi ve İstanbul'da Tramvay Iş̧̦ilerinin İ̧ctimai Durumu (Istanbul, 1949). Iş̧̧̧i Gücü was published in November I95 I by the Istanbul Electricity, Gas, and Motor Vehicle Workers' Union [İstanbul Elektrik, Gaz ve Motorlu Taşıt İşçileri Sendikası]. The newspaper continued publication until December 1979; Türkiye Sendikacılık Ansiklopedisi, II, p. I02.

44. "İşçiler hiç bir nizam ve zaman tanınmadan gelişigüzel, bazan 17-I 8 saat çalıştırılmakta, bir gün dahi istirahat verilmemektedir. İsteyenler kovulmaktadır. İşçilerin hayatı çimentolar üzerinde gece gündüz heder olup gitmektedir." "Mensucat Sanayii İşçileri Sendikasında Yapılan Mühüm Toplantı”, İşci Sesi (Bursa), 9 (23 October 1951), p. 3.

45. "Pazar Günü Ücret Ödenir Mi?”, İşçi Sesi (Bursa), is (4 December 1951), p. I. 
example, raged against one such employer, Kemal Köstendil, who compelled women workers to start working at sam and insulted them for being late. According to the newspaper, he never let the labor law through the gates of his factory. In a bill of law it proposed, the Southern Federation of Labor Unions [Güney İşçi Sendikaları Federasyonu] proposed incarcerating employers who failed to obey the labor law and those who fired workers to evade it. ${ }^{46}$

In their writings, poems, and interviews, workers, on the other hand, seemed to be acutely aware of the discrepancy between the high production level of the enterprises they worked for and their own poverty and ill-treatment. By pointing out workers' suffering, this rhetoric implied that the working class was being marginalized and treated as inferior despite their hard work and contribution to general wealth. Complaining about the unfair distribution of bonuses, for instance, Mustafa Kalaycıgil from the Sümerbank Kayseri Textile Factory wrote, "Production is high, sales are satisfactory/ But again we are povertystricken, we have deep wounds/ Our sorrow is narrated here and there/ We have the problem of justice, our problem is with bonuses." ${ }^{77}$ Similarly, at the Bursa Merinos Factory, Isş̧i Sesi underlined the disparity between the magnificence of the factory and the impoverishment of its workers. ${ }^{4}$ Isş Yolu [Labor Way], in the same vein, astutely reminded the Democrat Party of its promise to "distribute the profits of state enterprises to peasants, farmers, workers, and private entrepreneurs", and demanded a share of the annual profits of the Sümerbank enterprises for workers who "created that profit at the expense of their lives". ${ }^{49}$ Sendika Yolu criticized the management of the Nazilli Textile Factory because it did not invite its workers to celebrations to mark the factory's twelfth anniversary and did not commemorate the victims of production (istibsal kurbanlari). ${ }^{\circ}$

46. "Güney İşçi Sendikları Federasyonu Delegelerinin İstanbul'da Toplanan Türk-İș Kongresine Yaptıkları Kanun Teklifi”, Isşçi Haberleri, I4 (19 August 1953), p. 4. Isşçi Haberleri [Worker's News] was published between April I953 and January I954 on a weekly basis (it ran to thirty-three issues). It was the official newspaper of the Sümerbank and Milli Mensucat Factories Workers' Union [Sümerbank ve Milli Mensucat Fabrikaları İşçileri Sendikası] which had been founded in Adana; Yüksel Akkaya, "Çukurova'da Sendikacıllk”, pp. 192-193.

47. "İstihsal yüksekte, satış yerinde/Yine zavallıyız, yara derinde/Derdimiz söylenir dillerde dilde/Adalet derdi var, derdim pirimde"; Mustafa Kalaycıgil, "Derdim Pirimde", Gayret: Kayseri Tekstil Sanayii Iş̧̦ileri Sendikası Organı, 34 (9 June 195I), p. 4. Gayret began publication in September I950 as the official newsletter of the Kayseri Textile Industry Workers' Union [Kayseri Tekstil Sanayii İşçileri Sendikası].

48. T., "Merinos'da Bir Saat", İşçi Sesi (Bursa), I4 (27 November I95 I), pp. $2,4$.

49. Sendikacı, "En Hakl İsteğimiz: İșçi Temettü İkramiyesi", Ișs Yolu (Karabük), 22 (I December 1952), p. I. Is Ys Yolu started publication in January 1952 in Karabük. It was the official newspaper of the Iron and Steel Workers' Union [Demir Çelik İşçileri Sendikası].

50. Cevdet Şigay, “i 2’inci Yil”, Sendika Yolu, 36 (I 5 October i949), p. I. 
Workers' demands were not limited to the amelioration of poor material conditions. In this period, the demand for respectful treatment at the workplace and, more generally, in society became increasingly central to workers' discourse. In this regard, complaints about the insulting behavior of foremen and other supervisors became commonplace in labor newspapers. Foremen and supervisors were frequently excoriated for treating their subordinates with arrogance and contempt. According to numerous reports in labor newspapers, foremen used every available method to extend their sway over workers. Workers associated the contemptuous and cruel treatment of overseers with their low character and abuse of their authority. Moreover, there is no real sign that workers made a distinction between supervisors in private factories and the managers of state enterprises. They were perceived as equally abusive and paying little or no regard to workers' problems. ${ }^{\text {SI }}$

Among other forms of mistreatment, cursing and beating were constant sources of criticism among workers. During his trip to Gaziantep, the President of the Çukurova Trade Union Federation [Çukurova İşçi Sendikaları Birliği] heard workers' complaints about abusive employers. One example he cited was quite telling. An employer in Gaziantep had beaten one of the workers with his walking stick until the stick finally broke. Then he blamed the worker for having a tough back and claimed compensation of io lira for the broken stick. ${ }^{52}$ The same federation also filed a complaint about the Director of the Seyhan Bureau of the Labor Agency for affronting the dignity of workers by calling them scrap (paçavra). According to the local labor newspaper's report, the Minister of Labor summarily dismissed him in response to the Federation's protest. ${ }^{53}$ In this

5. For instance, complaining about the prevalence of beating and other forms of physical mistreatment, Tevfik Erdem likened the Sümerbank Nazilli Textile Plant to the "civilization with whip" (kamçılı medeniyet); Tevfik Erdem, "Kısımlarda Eli Kamçılı Beyler”, Sendika Yolu, 8 (6 October 1948), p. 2. On this point, see also Can Nacar, "Ekmeğin Yokluğunu Bilirim, Kıtlı̆̆ı Gördüm: İkinci Dünya Savaşı Yıllarında Kentsel Alanlarda Emekçiler”, Praksis, ı6 (2007), pp. 195-217.

52. "Gaziantep Mensucat Sanayi İşçilerinin Toplantısı", İşçi Sesi (Adana), 25 (I 3 December I950), p. 2. The first issue of İş̧i Sesi was published in Adana in June 1949 by the Çukurova Textile Industry Workers' Union [Çukurova Mensucat Sanayii İşçileri Sendikası]. Over two

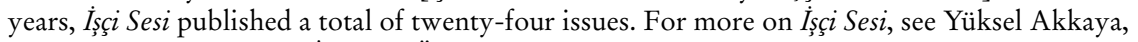
"Yerel Sendikal Basında Isşç Sesi Örneği”, Toplumsal Tarih, 53 (1998), pp. 39-44. The same newspaper recounted another incident when the local gendarmerie unit raided the Rasim Dokur Factory in Mersin at the request of the owner of the factory. Soldiers bound the hands of eight workers and clubbed the rest of them. The newspaper also reported that the prosecutor and judge said "Let's get rid of these hooligans". Workers sent telegrams to the Prime Minister, the President of the Parliament, and the Minister of Domestic Affairs to protest these unlawful acts; "Bir Kaymakam ve Jandarma Komutanının Marifetleri: Memlekette Kanun Yok mu?”, İşç Sesi (Adana), 25 (i3 December 1950), pp. I, 3.

53. "İşçileri Paçavralıkla İtham Eden Müdürün Vazifesine Son Verildi”, İş̧̧i Sesi (Adana), 25 (I 3 December 1950), p. 2. 
period, workers and their representatives became increasingly vocal about all kinds of insulting treatment of workers at the hands of supervisors and employers. $\dot{I}_{s}$ Yolu, for instance, reported that the chief of the maintenance department at the Karabük Steel Plant made twenty workers move his personal furniture from his home to another domicile during working hours. The newspaper sarcastically noted that "the tyranny and mentality of the past that we thought died a long time ago have been resurrected". ${ }^{54}$ Similarly, N. Köklü, a worker at the blending section of the Tekel cigarette factory in Izmir, employed a reference to the recent past when complaining about his department chief, who constantly insulted and punished workers without any reason. "He is using the whip of despotism during the time of democracy", bemoaned this worker."s

Several examples in worker newspapers clearly demonstrate that women workers frequently suffered from abuse and harassment at the workplace. İşciye Hizmet [Service to the Worker], for example, furiously warned the supervisors and foremen of a tobacco company in Izmir who swore at a female worker and beat her, implying that they would come to regret the consequences of these kinds of act. ${ }^{56}$ In a similar vein, Ayşe Yüksel, possibly a worker at the Sümerbank Nazilli Textile Factory, expressed the disparaged status of female factory workers and general public scorn directed at them in these verses: "Worker girls are looked down on here/ Our misfortune is subject to ridicule/ There is no manicure, no nail polish, no lipstick in our dreams/ We'll beat our misfortune with our future." 57

In this period, workers also became increasingly resentful of the hierarchical relations inside the gates of the factory. Gayret [Endeavor], for example, harshly criticized the Sümerbank factory's gatekeepers for beating an apprentice whose only fault was to have used a route prohibited to workers to get to the dining hall. Gayret's language drew attention to the differential treatment of officials and workers while demonstrating an awareness of their degradation and exclusion: "It is a bitter fact that the gatekeepers respectfully greet people with the exception of the workers. They verbally insult people who are dressed in shabby clothes or who wear overalls. We see that class difference has been established at this enterprise." 58 As Gayret's critique illustrates, inequality between the managers and workers became increasingly problematic at the workplace.

54. "Yaşayan hortlak", İş Yolu (Karabük), 30 (I April 1953), p. 2.

55. N. Köklü, "Fakat Alem Berdevam", İşçiye Hizmet, 4 (28 May 1953), p. 4.

56. M. Sait Yanlı, "Kadın İşçilerimize Hürmet Edelim”, İşçiye Hizmet, 2 (I4 May 1953), p. 3.

57. "Çok hakir görülür işçi kızlar bizde/ Alay ediliyor kara talihimizle/ Manikür yok, oje yok, ruj yok hayalimizde/ Yeneceğiz kara bahtı istikbalimizle”; Ayșe Yüksel, "İşçi Kızlar”, Sendika Yolu, I (I 8 August 1948), p. 2.

58. "İç Hizmetler Şefliğinin Nazar-1 Dikkatine”, Gayret: Kayseri Tekstil Sanayii İşçileri Sendikası Organi, 35 (I6 June I95 I), pp. 3-4. 
Gayret carried an essay questioning the existing order at the Kayseri Sümerbank Textile Factory's dining hall, where official personnel sat separate from the workers. The newspaper called for a common dining hall and forcefully demanded the extension of some privileges to workers which until then were enjoyed exclusively by white-collar personnel. In a similar vein, $\dot{I}_{s c ̧ i}$ Sesi expressed its resentment that in some workshops of the Hereke Carpet Factory bonuses (bursa) were withheld from workers while being granted to foremen and foreman assistants. The newspaper also stated that this decision was made arbitrarily by factory managers. ${ }^{59}$ Reporting similar differential treatment between railway workers and officials, Iş̧̧inin Sesi (Eskişehir) bitterly asked: “Isn't the worker a laborer of this state?" ${ }^{60}$ Evidently, as workers felt these discriminations keenly, they found them utterly humiliating.

This new political and cultural environment also encouraged workers to think critically about their past experiences of inequality as well as all sorts of discrimination they encountered at the workplace and throughout society at large. Narrating his experiences in the Zonguldak coal mines during World War II, a worker, Ramazan Karameșe, recalled indignantly how the wartime government treated officials and workers differently:

Workers could not even find sugar for five lira while officials used to pay only I 20 kuruş; workers were deprived even of the canvas (kaput bezi) to don while the officials were given suits and their families enjoyed high-quality cloth for their overcoats. In the mornings on their way to the mines, workers ate boiled mashed corn while officials enjoyed first-quality bread. ${ }^{61}$

Thanks to the Turkish nation's determination, Karameşe argued, "this mentality and its representatives have vanished from the scene of the country”. Karameşe ended his memoirs with a strong, bitter warning that if the (DP) government wanted to pursue a dilatory politics on the labor question, "they'd better study the lessons of the past carefully". ${ }^{62}$ As these

59. "Hereke Fabrikası İhzar Dairesi İşçilerine Prim Verilmiyor: Bu İşçilerin Hakları Ödenmelidir", İş̧i Sesi (Bursa), I I (6 November I95 I), p. 2.

60. "İşçi bu devletin emektarı değil mi ?”; Rıza Tetik, "Kanunda Eşitlik Bekliyoruz!”, İşçinin Sesi, 8 (30 December 1951), p. I.

6I. "İdare halkı ikiye ayırmış, öz evlat memur, üvey evlat işçi. İşçi beş liraya şeker bulamaz, memur I 20 kuruşa şeker yer. İşçi sırtına giymeye kaput bezi bulamaz, memurların kendilerine elbiselik kumaş ailelerine mantoluk kumaș verilir. İşçi sabahları ocağa giderken ekmek yerine misır haşlaması lapa yer, memurlar birinci nevi ekmek yer"; Ramazan Karameșe, "Ücretli İș Mükellefiyeti ve Türk İşçisinin Bu Yolda Harcandığı Günler”, Eskişehir Iş̧̦i Postası, 37 (I 8 April 1953), p. 2. Eskişehir Iş̧̦i Postası started life as the official newspaper of the Sakarya Trade Unions' Federation in 1952. It is not clear how long the newspaper continued to be published. 62. For more on the negative impact of World War II on workers, see Mehmet Șehmus Güzel, "İkinci Dünya Savaşı'nda İşçiler ve Sermaye”, Mülkiyeliler Birliği Dergisi, I 50 (1992), pp. 3 I-4I; Can Nacar, "Everyday Experiences of Working Class People in the Second World War Years” (M.A. thesis, Boğaziçi University, Istanbul, 2004); Ahmet Makal, “65. Yılında Milli 
examples suggest, workers increasingly sought to obliterate distinctions between themselves and their supervisors in the period under consideration. In criticizing the disparity between the government's treatment of workers and officials, workers evidently asserted their self-worth and, implicitly or explicitly, questioned the alleged superiority of white-collar employees.

The specific experience and unique language that I explore in this article contributed positively to the development of a more radical working-class politics in the I960s and I970s. A close examination of labor newspapers suggests that in this period workers and their representatives began to develop a self-confident language. This new political culture and language was built on the critical assessment of the corporatist construction of labor relations and the rejection of the idea that employers and workers were members of the same (national) family. On the other hand, it was based too on an energetic struggle to overcome the despicable image of the worker in society and even among laborers as well. This may not be "the language of class" (at least not in the Marxist sense of the word). Nevertheless, it opened channels which enabled workers to challenge the legitimacy of a social and economic order in which workers suffered from all kinds of deprivations. Subsequent labor movements in Turkey critically adopted this language and elaborated it further over the following years. How much this discourse was transformed under the highly radicalized atmosphere of the i 960 s and i 970 s should be subject to further research.

Korunma Kanunu, Çalışma İlişkileri ve İş Mükellefiyeti Üzerine Bir İnceleme”, Toplum ve Bilim, I02 (2005), pp. 55-9I; Murat Metinsoy, İkinci Dünya Savaşı'nda Türkiye: Savaș ve Gündelik Yașam (Istanbul, 2007). 